Regional and Business Studies (2018) Vol 10 No 1, 39-56

Kaposvár University, Faculty of Economic Science, Kaposvár

doi: $10.33568 /$ rbs.2334

\title{
A Few Steps AHEAD THE STATE OF KaZAKHSTAN'S PHARMACEUTICAL INDUSTRY
}

\author{
Dinara Aliyeva \\ Kaposvár University, Faculty of Economic Science, H-7400 Kaposvár Guba S. u. 40.
}

\begin{abstract}
The openness of the economy to the world market has many advantages but the lack of the protection of the domestic industry also imposes problems on the development of the domestic economy. In this sense, Kazakhstan, as part of the global market, is seeking its way in case of pharmaceutical industry. Currently the pharmaceutical sector is still in infancy stage of development to attempt the formation of an own independent pharmaceutical industry, the government has utilized several state programs and certain measures to stimulate the development of the pharmaceutical industry. The pharmaceutical market in Kazakhstan depends on foreign import drugs. In this article, we are considering the problems of Research and Development of original drugs in Kazakhstan. This paper explains the present barriers of the locally produced original drugs. The paper elaborates to eliminate public mismanagement, ineffective allocation of finance, to avoid loopholes in legislation (patent, fiscal, tax and preferences), to improve a cluster collaboration platform and economic barriers, commercialization technologies and not sufficient qualification of personnel and marketing and others. The theoretical and practical methods as well as administrative instruments of public services show the necessity of the adaptation of new approaches. This measure should be based on well-known overseas practices and legislative features that need to be applied accurately taking into account the specifications of Kazakhstan (legislation system, automation and digitalization process, big data, market circumstances and globalization impact and others). The paper is based on quantitative and qualitative data from scientific sources and legislation, official statistics, documents.
\end{abstract}

Keywords: R\&D, innovation, pharmaceutical industry, foreign investors, commercialization

\section{LITERATURE REVIEW}

Private and public sources also coexist in pharmaceutical R\&D. The division of labour in pharmaceutical R\&D between the two sectors is related, at least in principle, to the nature of the knowledge that is fostered (WHO, 2001). In most cases, the discovery of important new drugs is made by public institutions, which later license their development and exploitation to private firms. Some $70 \%$ of drugs with therapeutic gain were produced with government involvement (UNDP, 1999).

Innovation in pharmaceuticals relies increasingly on the knowledge gleaned from preceding innovations and on generally available techniques (Merges and Nelson, 1994), (Long, 2000). 
R\&D involves discovery [preclinical studies] and development [clinical studies] of New Chemical Entities also known as New Molecular Entities. It is worth noting that of about 10,000 NCEs investigated to potentially treat a disease, only 250 might make it to animal testing and, of these, approximately 5-10 will qualify for testing in humans. Between 19 and 30\% of Investigational New Drugs that begin Phase 1 trials make it to marketing (DiMasi, 2001).

Successful technology commercialization (TC) is important for the survival in today's competitive markets (Cooper, 2000). Mitchell and Singh (1996) view TC as 'the process of acquiring ideas, augmenting them with complementary knowledge, developing and manufacturing saleable goods, and selling the goods in a market.' This process begins with product conception; it includes the product definition, design, prototyping and pretesting stages; and it is consummated by effective product manufacturing and marketing. Successful TC allows the firm to satisfy its customers' needs in terms of the cost, speed, quality, and newness attributes of their technologies. However, TC requires strong and varied capabilities, especially in manufacturing (Ettlie, 1997). Manufacturing capabilities are grounded in the firm's people, skills, knowledge, processes, systems, and equipment. These capabilities can be assembled from different internal and external sources (Teece et al., 1997) and then deployed to create products and introduce them to the market in a timely manner.

Private, public and even non-profit organizations also mobilize their idle, unexploited, and underutilized discoveries, inventions and innovations into the open market. Indeed, the commercialization of new knowledge - basic and applied research, technology breakthroughs, and scientific developments - is an ecosystem of research and technology commercialization, which is the focus of this themed section. This ecosystem is essentially a market that includes research joint ventures, strategic alliances, and licensing agreements involving universities, research parks and firms, as well as the formation of start-up companies that focus on science and technology. To put it differently, we are witnessing the emergence of new organizational forms and functions that promote research, knowledge and technology commercialization, such as technology transfer offices (within for-profit and non-profit organizations), science parks, incubators, and industry-university research centres (Markman et al., 2008).

The first one is the rise in technology commercialization at research universities, which was stimulated by key legislation designed to promote the more rapid diffusion of technologies from universities to firms (e.g. the US Bayh-Dole Act of 1980 in the USA, and similar legislation in Europe, e.g. OECD, 2003), as well as an expansion of public-private partnerships by national governments (e.g. the US Commerce Department's Advanced Technology Program and the UK Small Firms Merit Award for Research and Technology Program). A second trend is the rise of public-private research partnerships (e.g. science parks) and public investment in programs that support research and commercial interactions involving universities and firms. While these developments are more prominent in the USA, the rate of investment in such activities is actually higher outside the USA (Phan et al., 2005).

Today's high drug prices are a direct consequence of a business model that uses a single payment to cover both the cost of manufacture of a drug and the cost of the 
R\&D carried out by manufacturers to discover it. A 20-year patent-based marketing monopoly is then granted to the drug's developers to prevent their prices from being undercut by 'generic' copies produced by manufacturers who do not have R\&D costs to recover. Preventing such 'free riding' on R\&D has become a global trade issue at the World Trade Organization (WTO) (Drahos and Braithwaite, 2002).

Unfortunately, monopoly-based business models have unpleasant side effects. Since the primary responsibility of any company is to maximize return on investment, it is unsurprising that there is pressure on pharmaceutical companies to set drug prices to whatever level gives the highest return, excluding those individuals who cannot afford to pay, rather than maximizing the number of patients treated. There is also pressure to misuse the power given by patents, using them as anticompetitive weapons to block innovation and extend marketing monopolies. And there are growing fears that the huge growth in the use of patents is in itself starting to inhibit research (CIPR, 2003).

Development of new drugs is a complex and costly process. It generally takes $10-$ 15 years, and studies have shown that it can cost between US $\$ 800$ million to US $\$ 2$ billion to get a new drug to market, with similar, or even higher, costs for development of pharmaceuticals (DiMasi and Henry, 2007).

There is little dispute about the importance to drug discovery of basic research at PSRIs under the traditional approach. Studies by Cockburn and Henderson showed the complex relationships between public and private research in the pharmaceutical industry (Cockburn and Henderson, 1997). Toole (2008) found a quantifiable correlation between investment in publicly funded basic research and corporately funded applied research: an increase of $1 \%$ in the funding of public basic research led to an increase of $1.8 \%$ in the number of successful applications for new molecular entities (compounds that have not been approved for marketing in the United States) after a lag of about 17 years. He found that a $\$ 1$ investment in public-sector basic research yielded $\$ 0.43$ in annual benefits in the development of new molecular entities in perpetuity (Toole, 2008).

Pharmaceutical companies hold international patent rights which give them the exclusive right to produce a new drug for a specific period, which may run into decades after its development. It is only after the lapse of the patent that generic formulations are allowed into the market according to the current drug production laws (World Health Organization, 2016).

\section{MAIN CHARACTERISTICS OF THE PHARMACEUTICAL SECTOR OF KAZAKHSTAN}

\section{The main economic circumstances in Kazakhstan}

The Kazakh relations with the usual data clearly show that the country is approaching the group of developed states, but its per capita GDP is still lagging behind the GDP of the OECD countries. According to the Gini indicator, income distribution is more evenly distributed than in OECD countries, and the expected life expectancy at birth is higher than expected on the basis of GDP. This is obviously related to the fact that relatively lower alcohol consumption and smoking are less widespread than even in 
the more developed countries of the surrounding CIS region. Kazakhstan is the $9^{\text {th }}$ biggest country in the World (Table 1). This is a great and special possibility for the Kazakh pharmaceutical industry. The low population density and the big territory would provide a niche for original drugs based on natural herbs collected from untouched «virgin» areas.

Table 1

\section{Some indicators of Kazakhstan}

\begin{tabular}{|l|c|c|c|}
\hline Name indicator & $\mathbf{2 0 0 1}$ & $\mathbf{2 0 1 6}$ & $\mathbf{2 0 1 7}$ \\
\hline Population in thousand & 14851 & 17918 & 18157 \\
\hline Territory in square kilometre & 2717300 & 2724900 & 2724900 \\
\hline GDP, current USD billion & 22.15 & 137.3 & 159.4 \\
\hline GDP/capita current USD & 1490 & 7714 & 8837 \\
\hline Poverty rate (2,5 USD/day/capita) in 2010 year & $0.7 \%$ & $0.1 \%$ & $0.0 \%$ \\
\hline Poverty rate (5 USD/day/capita) in 2010 year & $19.6 \%$ & $8.8 \%$ & $5.1 \%$ \\
\hline Gini coefficient & 0.366 & 0.278 & 0.287 \\
\hline Life expectancy at birth (years) & 65.76 & 72.41 & 72.95 \\
\hline
\end{tabular}

Source: The Ministry of National Economy of the Republic of Karakbstan Committee on Statistics, 2018

\section{The transformation of the sector to market-based economy}

According to economists and politicians of Kazakhstan, the pharmaceutical industry is one of the most important pulling sectors of the Kazakh industry. They use phrases like «best prospect industry in Kazakhstan». Maybe this optimistic view is not just an overstatement, meanwhile the real story of the industry started only in 1996 when the DE monopolization happened. Eugene Brovko and Alexey Klochko clearly stated in their study: in «Kazakhstan pharmaceutical market started its formation in the middle 1990s. In 1994, the State Joint Stock Holding «Pharmacia» owning 1832 pharmacies carried the provision of drugs in the country. After the DE monopolization of the Holding and privatization of its pharmacies, the national drug provision system was destroyed. In 1996, transformation processes allowed developing a drugs provision system based on market relationships» (Brovko and Klochko, 2017).

In the light of the figures, an outside viewer would hardly understand why it is the best prospect industry in Kazakhstan. As shown in the figure below, this industry accounts for less than 1\% of Kazakhstan's industrial production and its contribution to exports is insignificant (Figure 1).

However, it is true that the production of the industry is growing rapidly, with nearly three and a half times the domestic production. A near goal is that at least half of the domestic drug supply should be satisfied by domestic production. One of the most important issues for the future of the industry is whether or not this industry has the chance to develop original drugs any time in the future. The other or the traditional solution would be to keep importing the original medicines from abroad - most of 
them mainly from the US and produce only the generic medicines in Kazakhstan's economy.

\section{Figure 1}

\section{Production and investments into Kazakhstan's pharmaceutical market}

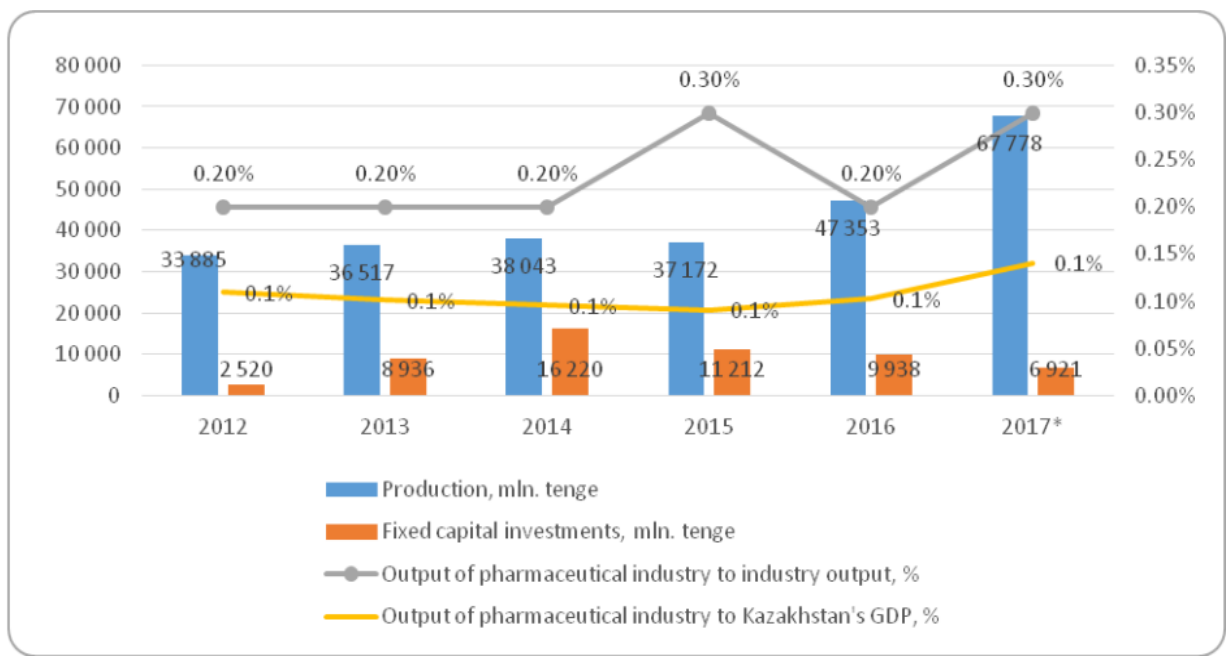

Sources: The Ministry of National Economy of the Republic of Kazakhstan Committee on Statistics, 2018; Shinkeyeva, 2017

Anyone who knows the Kazakh economy from inside of the country does not find it so weird that an industry below $1 \%$ has such a distinct attention. The Kazakh economy is characterized by the predominance of the oil industry and its closely related sectors, the ratios are often a bit distorted. More than $50 \%$ of the export comes from oil and gas export (Table 2).

\section{Table 2}

Macroeconomic Indicators, 2014-17

\begin{tabular}{|l|c|c|c|c|}
\hline Main indicators & $\mathbf{2 0 1 4}$ & $\mathbf{2 0 1 5}$ & $\mathbf{2 0 1 6}$ & $\mathbf{2 0 1 7}$ \\
\hline Nominal GDP (in billion KZT) & 39676 & 40884 & 46971 & 51967 \\
\hline Nominal GDP per capita (in USD) & 12807 & 10511 & 7714 & 8837 \\
\hline Real exchange rate change (KZT/USD) & -10.8 & -13.9 & -26.7 & 10.4 \\
\hline Merchandise exports, of which: & 80.3 & 46.5 & 37.3 & 49.3 \\
\hline Oil and gas exports & 53.6 & 26.8 & 19.4 & 26.4 \\
\hline
\end{tabular}

Source: Sarsenov and Aldiyarov, 2018

The Kazakh pharmaceutical industry, and also other sectors, was partly offset by the fact that oil and gas reserves made the Kazakh economy a raw material producing economy. The pharmaceutical industry was considered to be a high technology sector 
in the former Soviet Union and was developed in the centre mainly in Russia and not in peripheral republics like Kazakhstan.

The pharmaceutical industry is a specific market that is related to several spheres of economic and human activities. On the other hand, this industry plays a vital role in national security at the state level. This market is extremely changeable because of new technologies and interdependent on other sectors, for instance, chemical and agricultural.

Kazakhstan has developed the infrastructure of creating a line of original drugs. A half of this period has been devoted to a research program, and per sue, it is still under process. In turn, the government of Kazakhstan takes necessary steps for the adaptation transformation and free trade dictates the further integration process.

In this article we would like to show that the transformation of the pharmaceutical industry simultaneously opens up new opportunities and challenges. Kazakhstan has made a decision to pursue its independence from the world market turbulence: national security first. This measure should prevent any counterfeit drugs that can raise the issue of national security (causing death, disability and trauma).

\section{International agreements influencing the market}

While Kazakhstan is a member of the WTO, Kazakhstan is currently part of two economic co-operations that have a relatively close relationship with the most developed parts of the former Soviet republics. In 2010 Kazakhstan created a Customs Union with Russia and with Belarus.

It is difficult to evaluate and compare data with the KZT as the dollar exchange rate is changing significantly (Table 2). The actual data may be misleading, but the tendencies are apparent. An interesting comparison has been made by, for example, the Schneider Advisory Company on pharmaceutical prices. The price of five medicines (fever suppressors, Cold/flu, cough, analgesics) converted to dollars in Kazakhstan is twice as much as in Russia with the same customs debt.

The Customs Union also serves to protect the domestic industry. While previously the duty was duty-free, import duties around $5-12 \%$ as a result of entry into the $\mathrm{CU}$, protect imported goods from outside the CU. As more than four-fifths of the generic formulations of the medicines are used, the acquisition and production of these drugs will indirectly be supported within the CU countries.

On May 29, 2014 Kazakhstan and its Customs Union partners signed a treaty to create a common economic space known as the Eurasian Economic Union (EAEU). The EAEU is expected to further integrate their economies, and provide for the free movement of services, capital and labour within their common territory. The government of Kazakhstan has asserted that EAEU agreements comply with W'TO standards. Kazakhstan's government is optimistic that further integration within the EAEU will make Kazakhstan more attractive for foreign investment by expanding market access to those countries. Kazakhstan is a signatory of the Free Trade Agreement with CIS countries. In addition, as a member of the EAEU, Kazakhstan is party to the Free Trade Agreement between the EAEU and Vietnam (export.gov, 2017). 
Local manufacturers produce basic pharmaceutical products that do not require innovative technologies. Market demand for specific complex pharmaceuticals is met entirely by imports. The largest share of imported pharmaceutics belongs to the U.S. $18 \%$ followed by Germany and Russia with around $13 \%$ and $8.4 \%$ respectively. This is the reason why trade agreements have an important impact on medicines. Much of the generic pharmaceutical import still comes from Russia, while most of the original imports come from the USA and, to a lesser extent, EU Member States, such as Germany, Hungary or Poland. In the Kazakh pharmaceutical industry, one of the most important investors is the Polish «Polpharma».

\section{THE KEY ACTORS OF THE KAZAKH PHARMACEUTICAL INDUSTRY}

\section{The local players}

Kazakhstan wants to achieve 50\% self-sufficiency in pharmaceutical and health preservation products by 2018. In order to internationalize the industry, a major step in 2014 was the Good Manufacturing Practice (GMP) principles in the domestic pharmaceutical industry. In 2017, seven major companies in the pharmaceutical industry operated with these principles and they were certified due to this principle.

In Kazakhstan, there are about 24 manufacturers of medicines that are focused on the production of generic drugs, which should provide an own Research and Development of original drugs on the territory of the republic. "Among the high production areas were the Almaty region $52.8 \%$ of total domestic production), the South Kazakhstan region $18.3 \%$ and Almaty $12.4 \%$.

In the regional context, the largest contribution to medications production is made by Almaty city and Almaty region - it accounted for more than $61.2 \%$ or 10.9 thousand tons in 2016. The remaining 6.9 thousand tons were produced by enterprises of the South-Kazakhstan region (25.4\%), Karaganda region 7.5\% and other areas $5.9 \%$. At the end of 2017, experts did not expect significant changes in the regional structure.

At present the pharmaceutical industry in Kazakhstan is saturated with a variety of products, while the range of domestic products does not fully satisfy the domestic demand of consumers (The Ministry of National Economy of the Republic of Karakhstan Committee on Statistics, 2018; Shinkeyeva, 2017).

\section{Foreign investors and their distribution by countries}

The main foreign pharmaceutical companies are attracted from developing countries, from Poland, Turkey, Russia and China, and it is time to attract developed countries like: USA, Canada, UK, France, Germany, Denmark, Switzerland and Japan for Research and Development of Kazakhstan's original drugs (Table 3).

Chempharm-SANTO Company being a part of the international pharmaceutical group Polpharma (Poland), is implementing the largest investment project in the South Kazakhstan region to modernise the existing pharmaceutical production of Chempharm in accordance with Good Manufacturing Practice international standards. The Polish investor invested $\$ 37$ million in the plant (Uatkhanov, 2018). 


\section{Table 3}

\section{Top Five Partners (Million, USD)}

\begin{tabular}{|l|c|c|l|l|l|l|l|l|}
\hline \multicolumn{3}{|c|}{ Total } & \multicolumn{2}{c|}{ Equity Securities } & \multicolumn{2}{c|}{ Total Debt Securities } \\
\hline $\begin{array}{l}\text { All } \\
\text { Countries }\end{array}$ & 64.908 & $100 \%$ & $\begin{array}{l}\text { All } \\
\text { Countries }\end{array}$ & 9,196 & $100 \%$ & $\begin{array}{l}\text { All } \\
\text { Countries }\end{array}$ & 55.713 & $100 \%$ \\
\hline $\begin{array}{l}\text { United } \\
\text { States }\end{array}$ & 34.403 & $53 \%$ & $\begin{array}{l}\text { United } \\
\text { States }\end{array}$ & 4,859 & $52.8 \%$ & $\begin{array}{l}\text { United } \\
\text { States }\end{array}$ & 29.544 & $53 \%$ \\
\hline Japan & 4.375 & $6.7 \%$ & $\begin{array}{l}\text { United } \\
\text { Kingdom }\end{array}$ & 860 & $9.4 \%$ & Japan & 3.601 & $6.4 \%$ \\
\hline France & 3.749 & $5.7 \%$ & Japan & 774 & $8.4 \%$ & France & 3.456 & $6.2 \%$ \\
\hline Germany & 3.308 & $5.1 \%$ & Switzerland & 480 & $5.2 \%$ & Germany & 2.885 & $5.1 \%$ \\
\hline Canada & 2.382 & $3.7 \%$ & Netherlands & 157 & $1.7 \%$ & $\begin{array}{l}\text { South } \\
\text { Korea }\end{array}$ & 2.297 & $4.1 \%$ \\
\hline
\end{tabular}

Source: export.gov, 2017b

Pharmaceutical investment continues with state aid. Production in Hikma CIS Almaty will start in 2019 with a 6.5 billion KZT investment. Juldyz Kenan Co. LTD disposes of disposable medical plastic products for the manufacture of 1.7 billion KZT, Astana Pharmbiosyntesis invests in the manufacture of basic medicines 32.9 billion KZT. Chempharm-Santo's owner is the Polish Polpharma Group and their revenue in 2014 was about 55 million USD. The second biggest NOBEL Almaty Pharmaceutical Factory had only 22 million, meanwhile the other had less, between 7-2 million USD only (export.gov, 2017c).

\section{The structure of the healthcare system of Kazakhstan}

The organogram below shows the structure of the health system. The organogram shows that the health care system is still centralized and largely state-funded.

The non-commercial joint-stock company «Social Health Insurance Fund» was established in accordance with the Resolution of the Government of the Republic of Kazakhstan dated 01 July 2016 No. 389.

The Fund is a non-profit organization in the organizational and legal form of a joint-stock company, the sole founder and shareholder of which is the Government of the Republic of Kazakhstan.

For employers, the amount of deductions is stipulated as $1.5 \%$ of the employee's accrued income from 2018 to 2019, from January 1, 2020 - 2\%. Individuals do not pay between 2018 and2020, since 2020 they will pay from two monthly wages. At the moment, payment and contributions for compulsory social health insurance for individuals from January 1, 2020 have been postponed.

The state pays contributions for certain categories - in $20204 \%$ of the average monthly wage of the preceding two years of the current fiscal year, determined by the authorized body in the field of state statistics (paragraph 2 of Article 26 of the Law On Mandatory Medical Insurance) (Figure 2). 
Figure 2

The structure of the healthcare system of Kazakhstan

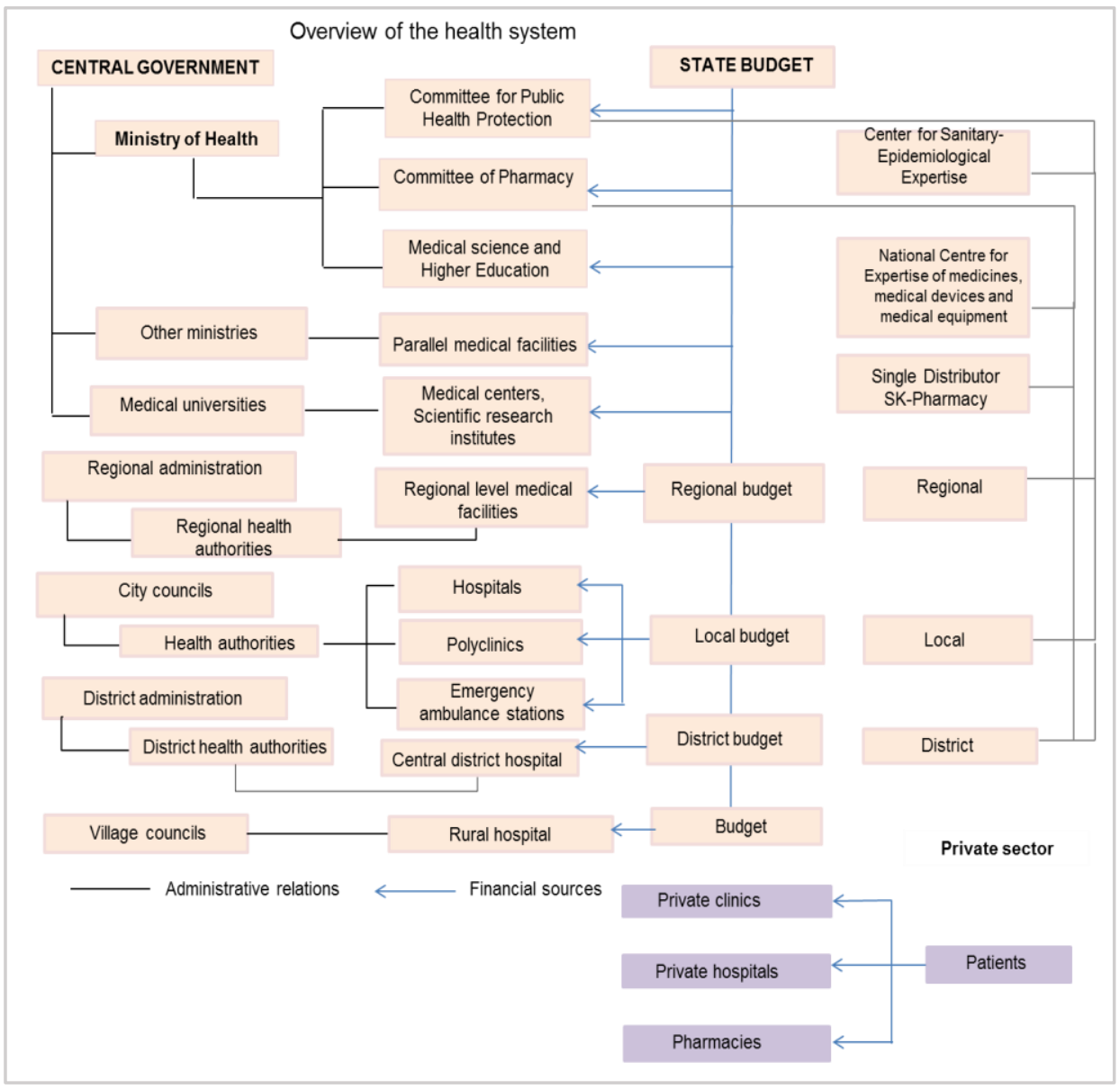

INNOVATION, R\&D POSSIBILITIES

The underutilised $R \& D$ network, the fragmented institutional infrastructure Kazakhstan has enough scientific and technical potential, but the implementation of R\&D results are very weak. There are research institutes in Kazakhstan and universities are not connected to industry, they focus their basic research on what industry can hardly benefit from and as a result of this, in Kazakhstan those patents are very rare from which the industry could develop brands. Basically Kazakhstan had some research institutes but they were not connected to the industry and their performances were not evaluated according to the practical implementation of their research or the financial success of their activity. High-tech product industrial innovations came from the Soviet system and Kazakhstan used to be on the periphery of the Soviet system. 
In Kazakhstan, there is a decline in the clinical trials market. So, in 2015, only 12 clinical trials were conducted, which is 3 times lower than in 2014. All clinical trials were conducted only by domestic manufacturers. The decrease is due to the obsolete regulatory framework, as the Rules for the conduct of clinical trials and (or) trials of pharmacological and medicinal products, medical devices and medical equipment were approved in November 2009. The main barriers for attracting international clinical research to Kazakhstan include: insufficient experience of the country's participation in clinical research; the absence of a register of clinical studies conducted in Kazakhstan; insufficient number of medical institutions for conducting clinical trials, since clinical research is carried out mainly by universities and research institutes; insufficient number of experienced researchers. Insufficient number of research institutions reduces the country's attractiveness for conducting clinical trials. Terms for the approval of clinical trials, which are 120-160 days, are a barrier to the participation of Kazakh medical institutions in international clinical trials. In addition, there is no regulatory procedure in Kazakhstan that regulates the importation of equipment and medical devices for clinical trials.

Conducting international clinical research affects the development of medical science in terms of improving the level of skills of medical personnel, transfer of advanced technology. The sponsor of the Clinical Research provides equipment, which is then donated to the clinic for free. Thus, the conduct of clinical research can become a locomotive for the development of medicine. The main barriers to conducting clinical trials in the Republic of Kazakhstan are the incompatibility of medical organizations with the criteria for accreditation for conducting clinical trials, as well as the shortage of qualified specialists with GCP certificates.

The consequences of the previous system still influence Kazakhstan's R\&D activity. Research institutes belonging to the public sector are mainly academic institutions and the research activity almost totally misses from the private sector. The government finances academic institutions, but there is no connection between their budget and the practical implementation of their research results. The scientists are evaluated according to their publication activity, if they want to be successful and get a better job, they have to publish in prestigious journals. If we evaluate our research institutes based on their publications, they are not among the best ones in the world. Personal career possibilities of the employees of research institutes contradict with the interest of the Kazakh economy.

The patent developed by the researches belongs to the institute, their financial benefit is only marginal. Certainly, their prestige is based on the patents as well, but their position in the scientific community comes from their publication activity.

All this makes it necessary to increase the efficiency and effectivity of the entire national research institution system and the system of commercialization of scientific R\&D.

Kazakhstan has several advantages in the field of developing and producing original drugs:

- possesses unique flora and uses several Scientific-Research laboratories that enable to create original specimen on botanic base; 
- big territory of the country gives possibilities for greenfield investments where the isolation of the investment site is important;

- political stability and geographical location of Kazakhstan can have an advantage for a potential Centre for international companies;

- custom free alliances of five countries created huge market opportunity (approximately 183,9 million people market) for the foreign investors;

- in cooperation with international companies the establishment of joint ventures gives opportunities for accessing high technologies;

- several government agencies are supporting the innovation activity with nonrefundable grants;

- well educated, but not properly used labour force.

Problems and barriers in front of the original drugs:

- economic barriers;

- commercialization activity is not developed;

- insufficient qualification of personnel.

Another problem in the domestic market is the lack of own innovative drugs. Kazakhstan is a country producing mainly generic drugs. The most of the domestic producers' products consist of low-cost medicines, which prevents the allocation of the required amount from the proceeds for $R \& D$.

\section{Existing economic barriers}

Tax and duties policy should be changed in favour of R\&D institutions, incumbent producers, investors and other stakeholders. Practically, the Government should adapt first minimal steps for creating a more competitive field:

- by reducing corporate income tax for the amount of expenses which is used for purchasing new technics, transferring technologies, implementation of GMP Rule;

- national producers consider the lack of tax agreements with some neighbours to be one of the barriers towards exports to those countries;

- reducing the corporate income tax.

\section{Improper commercialization}

The government of Kazakhstan strives for setting a new blueprint concerning innovation and development of knowledge intensive industries. Despite scientific and practical background, the search for an efficient way of product commercialization has become more crucial and actual so far, indeed.

The pharmaceutical market is divided almost equally into two major segments: State procurement and retail sales. State procurement of pharmaceuticals is implemented through tenders announced by regional and city health departments. A State-financed program funds state procurement of oncology and diabetic medicines. In 2009, the Ministry of Health set up SK-Pharmacy as a Single Distributor for supplying pharmaceuticals to State health institutions. The share of pharmaceuticals bought by the state through the Single Distributor system has increased and reached 
$85 \%$ by 2016 . The remaining $15 \%$ of pharmaceuticals is directly purchased by hospitals and consists mainly of items used less frequently. In 2016 the Single Distributor bought pharmaceuticals worth approximately $\$ 300$ million (Uatkhanov, 2018).

The weakest link in the creation of a national system of commercialization in Kazakhstan is the weak involvement of small and medium businesses in the process. In Kazakhstan, there are innovative developments that have effective results of the commercialization of innovative ideas. Experience shows that the introduction and commercialization of innovations is a complex process, and obtaining an economic effect involves several factors, including negative ones. Systemic approaches are needed for the formation of a national system for the commercialization of innovative scientific developments in order to support and protect domestic developers.

One of the reasons is that Kazakhstan has a traditional approach to commercialization based on technology, where the role of the state is to help the inventor to develop a scheme for promoting the result of the scientific idea. In this case, the lack of entrepreneurial skills is compensated by a professional expert who is able to make an assessment of the idea, to determine its further commercial prospects, thereby eliminating risks. However, very progressive ideas with market potential do not often provide economic success, since marketing research is not conducted sufficiently and the managerial skills of the inventor are missing.

\section{Not Sufficient Qualification of Personnel}

One of the limiting factors in the development of the pharmaceutical industry is the high demand for qualified personnel. In the market there is an insufficient level of professional training and a shortage of qualified personnel.

The discipline of clinical pharmacology is rapidly developing in the world pharmaceutical market. Clinical pharmacology studies various problems of drug therapy - the methodology of clinical trials, the metabolism of drugs, molecular pharmacogenetics, the analysis of drug intake, etc. The main direction of this discipline as a specialty is the study of questions concerning the health of patients. Specialists working in this field are trying to narrow the gap between drug manufacturers and clinicians. At present, there are about 200 clinical pharmacologists in Kazakhstan, of which only 5\% are graduates, the rest have certificates. Moreover, there is no status of clinical pharmacologists, regulatory legal acts, quotas for training in the speciality of clinical pharmacology (The Ministry of HealthCare of the Republic of Kazakistan, 2017).

The number of employees increased from 16578 thousand in 2003 to 22985 thousand in 2016 performing R\&D. In fact, there is a problem of a shortage of personnel not only of skilled labour in the pharmaceutical, medical, agricultural and humanity fields in general. (The Ministry of National Economy of the Republic of Kazakhstan Committee on Statistics, 2018).

Moreover, Table 4 illustrates that there is less investment in medical, agricultural, public, humanitarian domain than in technical and natural sciences, and the ratio went down in medical science from $6 \%$ in 2004 to 3\% in 2016, meanwhile the 
absolute number was increasing. The overall expenditures are 5 times higher. Also public science decreased from 4\% in 2004 to 1\% in 2016 (Table 4).

Table 4

Gross domestic expenditure on $R \& D$ by field of science

\begin{tabular}{|l|c|c|c|c|}
\hline Sector of sciences & $\mathbf{2 0 0 4}$ in million KZT & $\mathbf{0}$ & $\mathbf{2 0 1 6}$ in million KZT & $\mathbf{\%}$ \\
\hline Technical & 7317 & $52,78 \%$ & 30193 & $45,34 \%$ \\
\hline Natural & 3405 & $24,56 \%$ & 23496 & $35,28 \%$ \\
\hline Agricultural & 1302 & $9,39 \%$ & 6885 & $10,34 \%$ \\
\hline Medical & 889 & $6,41 \%$ & 2278 & $3,42 \%$ \\
\hline Public & 583 & $4,20 \%$ & 1072 & $1,61 \%$ \\
\hline Humanities & 367 & $2,65 \%$ & 2676 & $4,02 \%$ \\
\hline Total & 13863 & $100 \%$ & 66600 & $100 \%$ \\
\hline
\end{tabular}

Source: The Ministry of National Economy of the Republic of Karakhstan Committee on Statistics, 2018

As it might be assumed, if the aims are to play a crucial and leading role in this market, countries should pay to keep a high number of employment, like Germany 114 thousand, France - 98,6 thousand, UK - 61,5 thousand, and Hungary - 23 thousand, which had a high number of employment in 2015.

\section{THE STRATEGIC STEPS NECESSARY FOR R\&D OF ORIGINAL DRUGS IN KAZAKHSTAN}

The development of the country's economy and the increase of the competitiveness of enterprises are impossible without the large-scale costs of economic entities for R\&D.

We consider each step separately here in details for Research and Development of original drugs in Kazakhstan:

1) The analysis aimed at studying the market review, the volume and growth rates of the market, the ratio of the number of original and generic drugs and distribution of drugs;

2) Marketing research aimed at studying the structure of the market, the consumers of products, studying the range and demand as well as a customer analysis, the segmentation of the market for consumers of the drugs studied, analysis of the internal and external competitive environment of the drugs, the determination of the optimal retail price of the new drugs;

3) Identifying ways to advance the plan and budget to promote original drugs is the preparation of a plan for promotion and budgeting;

4) Financing through the state budget or by attracting foreign investment for Research and Development of original drugs. Currently, the Ministry of Education and Science of the Republic of Kazakhstan jointly with the World Bank, is implementing a project to stimulate productive innovation. The joint 
project of the Government of Kazakhstan and the World Bank is aimed at strengthening the capacity of key institutions of the national innovation system, it involves the introduction of market mechanisms for selecting and supporting innovative projects and technological start-ups, as well as encouraging the participation of the private sector in them. The aim of the Project is to stimulate high-quality, relevant research and the commercialization of technologies (The Ministry of Education and Science of the Republic of Kazakhstan, 2018).

It is also possible to receive grants from National managing holding Baiterek, Centre of engineering and technology transfer, Enterprise Development Fund DAMU, Kazagromarketing, Centre for technology transfer and commercialization, KazagroInnovation can provide a significant amount of funding, accumulate a large amount of scientific and technical information and has a significant impact on the development trends of Kazakhstan's science;

5) The share of domestic R\&D expenditures from gross domestic product decreased from $0.25 \%$ in 2003 to $0.14 \%$ in 2016 . The number of institutes and universities (enterprises) are 383 performing scientific Research and Development. Organization and conduct of Research and Development of original drugs should be made in accordance with the quality standards of good laboratory practice and good clinical practice.

The GLP standard is a system of norms, rules and guidelines aimed at ensuring consistency and reliability of laboratory research results. The main task of GLP is to ensure the full traceability and recovery of the entire course of the research. This is of research of agricultural products, medical research, food additives and original drugs (Yestaev, 2018).

GCP is the quality of clinical practice, covering the planning, implementation, completion and verification, analysis of results, reporting and documentation that ensures the scientific significance of research, their ethical acceptability and the full documentation of the clinical characteristics of the drugs studied. The influence of clinical pharmacology on the process of creating new drugs is mostly pronounced when conducting clinical research;

6) The rights to an invention are protected by a patent, which is issued based on the results of an examination conducted in accordance with the Patent Law of the Republic of Kazakhstan. Expertise of applications for the grant of patents for inventions is carried out by an expert organization - National Institute of Intellectual Property of the Ministry of Justice of the Republic of Kazakhstan. The patent certifies the priority, authorship and exclusive right to an object of industrial property. A patent for an invention is valid for twenty years from the date of filing an application. Regarding an invention relating to a medicinal product, a pesticide (toxic chemicals) for use that requires permits in the manner prescribed by the legislation of the Republic of Kazakhstan on permits and notifications, the period of validity of the exclusive right and the patent certifying this right may be extended at the request of the patent holder, but not more than five years. (National Institute of Intellectual Property, 2017);

7) The registration of the original drugs takes place at the National Centre for Expertise of medicines, in the case of medical devices and medical equipment it 
is the role of the Ministry of Health of the Republic of Kazakhstan to determine the safety and quality of medicines. The safety and quality assessment are carried out to confirm the safety and quality of products, including those withdrawn from the market if they are in doubt concerning their quality, pharmacovigilance and monitoring results of side effects of medicines and prevention of the circulation of counterfeit products on the market of the Republic of Kazakhstan. Assessment of safety and quality is subject to drugs imported into the Republic of Kazakhstan and medicines and medical products produced in the territory of the Republic of Kazakhstan (National Center for Expertise of Medicines, 2018).

8) Here I propose to consider the commercialization of technologies, since today there is the National Agency for Technological Development of the Baiterek Holding, which provides the commercialization of technologies for introducing (using) the results of scientific and (or) scientific and technical activities in their own production aimed at obtaining a positive economic effect. The financing condition is $50 \%$ of the applicant's own funds $/ 50 \%$ of the grant, but not more than 200 million KZT. Starting from 2012, it is possible to receive innovative grants through the National Agency for Technological Development for three types of grants: 1) Commercialization of technologies; 2) Technological development of enterprises; 3) Technological development of the industry (National Agency for Technological Development of the Republic of Karakbstan, 2018).

Moreover, in the framework of the Law of the Republic of Kazakhstan On State Support of Industrial Innovation Activities», tax and budget incentives for innovation infrastructure and enterprises aimed at producing high-tech products are envisaged;

9) Introduction of original drugs into production. In case of interest by pharmaceutical companies and obtaining mutually beneficial terms, the pharmaceutical company should be associated with Institutes and Universities and provide the responsibility of each party in terms of implementing Research and Development of original drugs. The Institute will be obliged to conduct market analysis, marketing of domestic and foreign markets, assess the profitability of products in conjunction with independent experts and harmonize the budget with state organizations, and conduct the Research and Development of original drugs. The University makes an agreement with a pharmaceutical company to provide qualified personnel. The pharmaceutical company will be obliged to introduce the original drugs into production and promote the products.

\section{CONCLUSION}

It is an important issue for a rapidly growing, but mainly oil-based economy to decide whether to develop independent industries such as the pharmaceutical industry or not. Kazakhstan has some intellectual capital related to the chemical industry because of the predominance of the oil industry. The question is whether this could be a sufficient basis for creating a specialized high-tech industry such as the pharmaceutical industry. The creation of original medicines would require a solid institutional background for the research of biochemistry and an industrial culture 
which satisfy the requirements of good manufacturing practice, and this is what largely lacking in Kazakhstan. The emergence and expansion of foreign pharmaceutical investors from US, UK, Poland and Canada, however, warns that the pharmaceutical market is open to both Russia and Asian countries and is easily accessible from Kazakhstan. Our research shows that the radical shift towards original drugs is more a desire than reality. However, the generic drugs market may have real reserves that the Kazakh pharmaceutical industry would have to resort to. For this, close cooperation between industry and state is essential. The industry should be prepared for innovations, but the government should create the favourable business conditions for such a development. The economic policy and regulation should break down the administrative barriers that hinder industry development and should provide better protection against imported generic drugs in the market. Over the next few years, the positive state discrimination of the domestic pharmaceutical industry is justified. Without positive discrimination, the newborn drug industry would not be able to strengthen and would disappear before it could turn out to be viable.

\section{REFERENCES}

Brovko, E., Klochko, A. (2017): Kazakhstan Pharmaceutical \& Healthcare Industries Overview. Business UPHARMA [online] <URL: https://slideshare.net/avigraf/ kazakhstan-pharmaceutical-healthcare-industries-overview-2017>

Cockburn, I., Henderson, R. (1997): Public-private interaction and the productivity of pharmaceutical research. Cambridge, MA: National Bureau of Economic Research. 1-36. p. doi: 10.3386/w6018

Cooper, G. (2000): Strategic marketing planning for radically new products. In: Journal of Marketing, 64. 1. 1-16. p. doi: 10.1509/jmkg.64.1.1.17987

Drahos, P., Braithwaite, J. (2002): Information feudalism: Who owns the knowledge economy? London: Earthscan, 253. p.

Ettlie, J.E. (1997): Integrated design and new product success. In: Journal of Operations Management, 15. 1. 33-55. p. doi: 10.1016/s0272-6963(96)00095-2

Markman, G.D., Siegel, D.S., Mike, W. (2008): Research and Technology Commercialization. In: Journal of Management Studies, 45. 8. 1401-1423. p. doi: 10.1111/j.1467-6486.2008.00803.x

DiMasi, .J.A. (2001): Risks in new drug development: Approval success rates for investigational drugs. In: Clinical Pharmacology \& Therapeutics, 69. 5. 297-307. p. doi: $10.1067 / \mathrm{mcp} .2001 .115446$

DiMasi, J.A., Grabowski H.G. (2007): The cost of biopharmaceutical R\&D: is biotech different? In: Managerial and Decision Economics, 28. 4-5. 469-479. p. doi: $10.1002 /$ mde. 1360

Long, C. (2000): Patents and cumulative innovation. In: Washington University Journal of Law and Policy, 2. 229-246. p.

Merges, R.P., Nelson, R.R. (1994): On limiting or encouraging rivalry in technical progress: The effect of patent scope decisions. In: Journal of Economic Behavior \& Organization, 25. 1. 1-24. p. 
Mitchell, W., Singh, K. (1996): Survival of businesses using collaborative relationships to commercialize complex goods. In: Strategic Management Journal, 17. 3. 169-195. p. doi: 10.1002/(sici)1097-0266(199603)17:3<169::aidsmj801>3.3.co;2-r

Phan, P., Siegel, D.S., Wright, M. (2005): Science parks and incubators: observations, synthesis and future research. In: Journal of Business Venturing. 20. 2. 165-182. p. doi: 10.1016/j.jbusvent.2003.12.001

Shinkeyeva, G. (2017): Kazakhstan's pharmaceutical industry. Rating Agency of the Regional Financial Center of Almaty. (RFCA) [online] <URL: https://en.rfcaratings.kz/2589>

Sarsenov, I., Aldiyarov, A. (2018): The quest for a new growth model: the urgency of economic transformation - country economic update. Kazakhstan economic update. Washington, D.C.: World Bank Group, 28. p.

Teece, D.J., Pisano, G., Shuen, A. (1997): Dynamic capabilities and strategic management. In: Strategic Management Journal, 18. 7. 509-533. p. doi: 10.1002/(sici)1097-0266(199708)18:7<509::aid-smj882>3.0.co;2-z

Toole, A.A. (2008): The impact of public basic research on industrial innovation: evidence from the pharmaceutical industry. New Brunswick, NJ: Rutgers University Department of Agricultural, Food and Resource Economics, 1-36. p.

Uatkhanov, Y. (2018): Kazakhstan domestic pharmaceutical production up 79.8 percent in 2017 [online] <URL: https://astanatimes.com/2018/03/kazakhdomestic-pharmaceutical-production-up-79-8-percent-in-2017/

Yestaev, E. (2018): Principles of good laboratory practice GLP will be introduced in Kazakhstan. PharmNews: [online] <URL: http://pharmnews.kz/>

\section{Other sources:}

CIPR (Commission on Intellectual Property Rights) (2003): Report. [online] <URL: http://www.iprcommission.org/>

export.gov (2017a): Trade Agreements [online] <URL: https://export.gov/apex/article> export.gov (2017b): Foreign Direct Investment and Foreign Portfolio Investment Statistics. [online] <URL: https://export.gov/article?id=Kazakhstan-foreigndirect-investment-statistics $>$

export.gov (2017c): Kazakhstan-Drugs-and-Pharmaceuticals. Schneider Group report. [online] <URL: https://www.export.gov/article?id=KazakhstanDrugs-and-Pharmaceuticals

National Agency for Technological Development of the Republic of Kazakhstan. (2018): Report [online] <URL: https://natd.gov.kz>

National Center for Expertise of Medicines (2018): Medical Devices and Medical Equipment [online] <URL: https://www.ndda.kz/>

National Institute of Intellectual Property (2017): The rights of invention. [online] <URL: https://kazpatent.kz/en

The Ministry of Education and Science of the Republic of Kazakhstan. (2018): Financing. [online] <URL: https://portal.fpip.kz/\#

The Ministry of HealthCare of the Republic of Kazakhstan. (2017): Clinical pharmacologists in Kazakhstan [online] <URL: https://dsm.gov.kz/en 
The Ministry of National Economy of the Republic of Kazakhstan Committee on Statistics (2018): Reports. [online] <URL: https://www.stat.gov.kz>

WHO (Commission on Macroeconomics and Health \& World Health Organization) (2001): Macroeconomics and health : investing in health for economic development : executive summary / report of the Commission on Macroeconomics and Health. [online] <URL: https://apps.who.int/ iris/handle/10665/42463>

WHO (World Health Organization) (2016): Generic medicines. In: WHO Drug Information 30. 3. 370-375. p. [online] <URL: https://www.who.int/ medicines/publications/druginformation/WHO_DI_30-

3_GenericMedicines.pdf?ua=1>

Corresponding author:

\section{Dinara AlIYEVA}

Kaposvar University

Faculty of Economic Science

H-7400 Kaposvár, Guba Sándor u. 40.

E-mail: dinarali80@mail.ru 